Praca oryginalna/Original research article

\title{
Zakażenia wirusowe u dzieci po przeszczepieniu komórek krwiotwórczych: raport 2016 Polskiej Pediatrycznej Grupy ds. Zakażeń Polskiego Towarzystwa Onkologii i Hematologii Dziecięcej
}

Viral infections in children undergoing hematopoietic stem cell transplantation: report 2016 of Polish Pediatric Infectious Working Group of Polish Society of Pediatric Oncology and Hematology

Jan Styczyński ${ }^{1, *}, K^{2} z y s z t o f$ Czyżewski ${ }^{1}$, Jowita Frączkiewicz ${ }^{2}$, Małgorzata Salamonowicz ${ }^{2}$, Olga Zając-Spychała ${ }^{3}$, Agnieszka Zaucha-Prażmo ${ }^{4}$, Jolanta Goździk ${ }^{5}$, Patrycja Zalas-Więcek ${ }^{6}$, Magdalena Dziedzic ${ }^{1}$, Krzysztof Kałwak ${ }^{2}$, Ewa Gorczyńska ${ }^{2}$, Alicja Chybicka ${ }^{2}$, Jacek Wachowiak ${ }^{3}$, Jerzy Kowalczyk ${ }^{4}$, Eugenia Gospodarek-Komkowska ${ }^{6}$, Mariusz Wysocki ${ }^{1}$

\footnotetext{
${ }^{1}$ Katedra Pediatrii, Hematologii i Onkologii, Szpital Uniwersytecki $n r$ 1, Collegium Medicum, Uniwersytet Mikołaja Kopernika, Kierownik: prof. dr hab. n. med. Mariusz Wysocki, Bydgoszcz, Polska

${ }^{2}$ Katedra i Klinika Transplantacji Szpiku, Onkologii i Hematologii Dziecięcej, Uniwersytet Medyczny,

Kierownik: prof. dr hab. Alicja Chybicka, Wrocław, Polska

${ }^{3}$ Klinika Onkologii, Hematologii i Transplantologii Pediatrycznej, Uniwersytet Medyczny,

Kierownik: prof. dr hab. Jacek Wachowiak, Poznań, Polska

${ }^{4}$ Klinika Hematologii, Onkologii i Transplantologii Dziecięcej, Uniwersytet Medyczny, Kierownik: prof. dr hab. Jerzy Kowalczyk, Lublin, Polska

${ }^{5}$ Ośrodek Transplantacji Uniwersyteckiego Szpitala Dziecięcego, Katedra Immunologii i Transplantologii Klinicznej, Uniwersytet Jagielloński Collegium Medicum, Kierownik: dr hab. Jolanta Goździk, Kraków, Polska

${ }^{6}$ Katedra i Zakład Mikrobiologii, Collegium Medicum, Uniwersytet Mikołaja Kopernika, Kierownik: prof. dr hab. Eugenia Gospodarek-Komkowska, Bydgoszcz, Polska
}

I N F O R M A C JE O A R T Y K U L E

Historia artykułu:

Otrzymano: 20.08.2016

Zaakceptowano: 23.11.2016

Dostępne online: 19.01.2017
A B S T R A C T

Background: Polish Pediatric Infectious Working Group of Polish Society of Pediatric Oncology and Hematology continues from 2012 the infections monitoring program in pediatric hematopoietic stem cell transplant (HSCT) and onco-hematology centers. Objective: Epidemiological analysis of viral infections in children and adolescents undergoing

\footnotetext{
${ }^{*}$ Adres do korespondencji: Katedra Pediatrii, Hematologii i Onkologii, Collegium Medicum im. L. Rydygiera w Bydgoszczy, Uniwersytet Mikołaja Kopernika, ul. Skłodowskiej-Curie 9, 85-094 Bydgoszcz, Polska. Tel.: +48 (52) 585 4860; fax: +48 (52) 5854867.

Adres email: jstyczynski@cm.umk.pl (J. Styczyński).

http://dx.doi.org/10.1016/j.achaem.2016.11.006

0001-5814/@ 2017 Polskie Towarzystwo Hematologów i Transfuzjologów, Instytut Hematologii i Transfuzjologii. Published by Elsevier Sp. $\mathrm{z}$ o.o. All rights reserved.
} 
Słowa kluczowe:

- zakażenia wirusowe

- przeszczepienie komórek krwiotwórczych

- dzieci

- epidemiologia

Keywords:

- Viral infections

- Hematopoietic stem cell transplantation

- Children

- Epidemiology
HSCT in pediatric centers in 2012-2013 and 2014-2015. Methods: Retrospective analysis of viral infections after 650 HSCT in children and adolescents. Results: An increase in incidence in 2014-2015 was observed (60.6\% vs 51.3\%; OR = 1.5; $\mathrm{p}=0.035)$ after allo-HSCT. Cumulative incidence after allo-HSCT (2012-2013 vs. 2014-2015) was: CMV - $28.0 \%$ vs. $29.2 \%$, BKV $-18.5 \%$ vs. $22.8 \%$, EBV $-15.5 \%$ vs. $24.3 \%$, ADV $-9.5 \%$ vs. $5.2 \%$, rotavirus $-9.1 \%$ vs. $5.6 \%$, VZV $-2.6 \%$ vs. $1.1 \%$, influenza $-0.9 \%$ vs. $3.4 \%$, HHV6 $-0.9 \%$ vs. $1.5 \%$, norovirus $0 \%$ vs. $2.2 \%$, RSV - $0 \%$ vs. $1.5 \%$, parainfluenza - $0 \%$ vs. $0.7 \%$, and MPV - $0 \%$ vs $0.4 \%$. Infections after auto-HSCT occurred in 8 (10.5\%) patients between 2012 and 2013 vs. 2 (2.6\%) between 2014 and 2015. Cure rate after viral infections has increased (2012-2013 vs. $2014-2015)$ for: $\mathrm{EBV}-90.7 \%$ vs. $100 \%$, ADV - $93.8 \%$ vs. $100 \%$, BKV $-94.2 \%$ vs. $96.8 \%$, CMV $-94.6 \%$ vs. $98 \%$, and remained $100 \%$ in infections with influenza, VZV, HHV6, rotavirus as well as in parainfluenza, RSV, and MPV. Decrease of deaths rate attributed to viral infections from $6.5 \%$ (2012-2013) to $0.7 \%$ (2014-2015) was observed after allo-HSCT. Conclusions: We found epidemiological trends in viral infections after HSCT in children: increase in incidence after allo-HSCT (increase EBV, appearance of CARV) and decrease after auto-HSCT. Decrease of deaths attributed to viral infections was observed in the last period of time.

(c) 2017 Polskie Towarzystwo Hematologów i Transfuzjologów, Instytut Hematologii i Transfuzjologii. Published by Elsevier Sp. z o.o. All rights reserved.

\section{Wstęp}

Zakażenia są jednym z głównych powikłań oraz przyczyn niepowodzeń przeszczepienia komórek krwiotwórczych (HSCT; hematopoietic stem cell transplantation). Zakażenia bakteryjne występują z podobną częstością po przeszczepieniu allogenicznym (allo-HSCT) i autologicznym (auto-HSCT), natomiast zakażenia grzybicze i wirusowe występują znacznie częściej po allo-HSCT, co wynika z możliwości występowania głębokich zaburzeń immunologicznych po allo-HSCT, związanych z niezgodnościami w HLA pomiędzy dawcą i biorcą, stosowanej terapii immunosupresyjnej i możliwej obecności GVHD.

W roku 2012 w polskich pediatrycznych ośrodkach przeszczepowych rozpoczęto program analizy występowania i terapii powikłań infekcyjnych (iPhot-13; Infections in Polish pediatric hematology, oncology and stem cell transplantation centers) [1]. Charakterystykę powikłań wirusowych u dzieci po HSCT w latach 2012-2013 przedstawiono w artykule opublikowanym w 2015 r. [2].

Ze względów klinicznych, w oddziałach przeszczepowych wyróżnia się zakażenia wirusami latentnymi (herpeswirusy, polyoma BKV) i sporadycznymi (wirusy grypy oraz inne wirusy oddechowe, ang. CARV; community-acquired respiratory viruses, a także wirusy przewodu pokarmowego: rotawirusy i norowirusy i inne) [3].

Celem tej pracy jest analiza zakażeń wirusowych u dzieci po HSCT leczonych w pediatrycznych ośrodkach przeszczepowych w latach 2014-2015 (program iPhot-15) w porównaniu z okresem 2012-2013 (program iPhot-13).

\section{Material i metody}

Retrospektywnej analizie poddano 650 przeszczepień komórek krwiotwórczych przeprowadzonych u dzieci i młodzieży w 5 ośrodkach Polskiej Pediatrycznej Grupy ds. Przeszczepiania Komórek Krwiotwórczych (PPGdsPKK) w latach 20122015, w polskich pediatrycznych ośrodkach przeszczepowych, w tym 308 HSCT w latach 2012-2013 (allo-HSCT-232, auto-HSCT-76) oraz 342 HSCT w latach 2014-2015 (allo-HSCT-267, auto-HSCT-75).

Przeprowadzono analizę częstości występowania oraz metody i wyniki leczenia zakażeń. W analizie uwzględniono zakażenia następującymi wirusami: latentnymi (cytomegalowirus - CMV, Epstein-Barr Virus - EBV, varicella-zoster virus VZV, HHV6, polyoma BK virus), sporadycznymi (adenowirus - ADV, grypa - INFL, pozostałe wirusy CARV [PIF - paragrypa (parainfluenza); MPV - metapneumovirus; RSV - respiratory syncytial virus], rotawirusy RV i norowirusy NV) oraz hepatotropowymi.

Diagnostykę zakażeń wirusowych po HSCT wykonywano metodą PCR z materiału uzyskanego z krwi, moczu lub płynu mózgowo-rdzeniowego. Wirusy CARV wykrywano metodą PCR $\mathrm{z}$ wymazu $\mathrm{z}$ dróg oddechowych. Badania w kierunku rotawirusów i norowirusów wykonywano metodą serologiczną.

\section{Analiza statystyczna}

Częstość występowania zakażeń porównano testem $\chi^{2}$. Częstości kumulacyjne występowania zakażeń oraz śmiertelność zależną od infekcji wirusowej (IRM; infection-related mortality) wyznaczono metodą Kaplana-Meiera i porównano testem log-rank. Ryzyko wystąpienia zakażenia określono w modelu Coxa. Ryzyko względne oceniono ilorazem szans (OR; odds ratio) z 95\% przedziałem ufności (CI; confidence interval).

\section{Wyniki}

W analizowanym okresie stwierdzono 469 zakażeń wirusowych (nie uwzględniając nawrotów zakażeń). W latach 


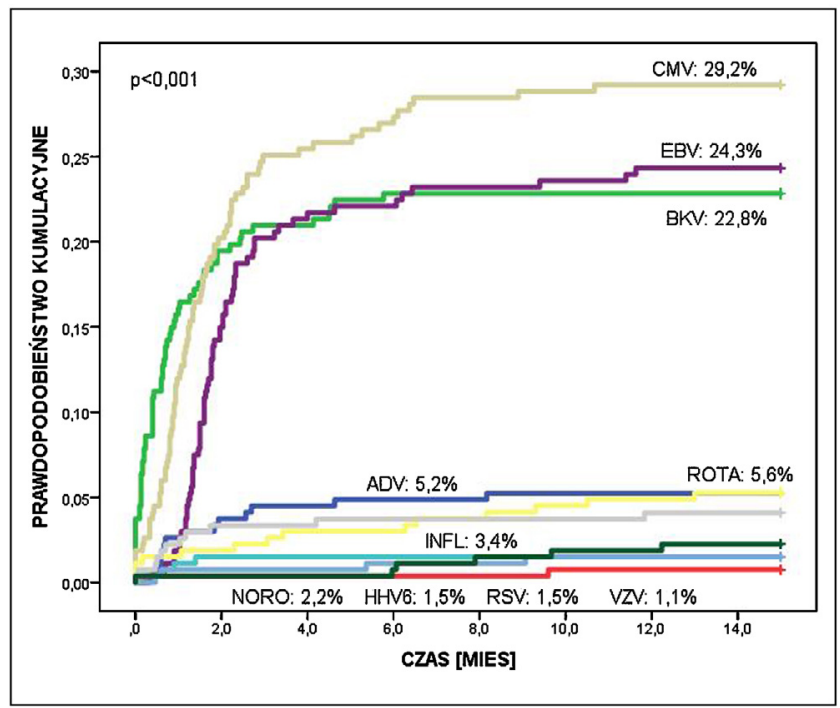

Ryc. 1 - Częstość zakażeń wirusowych po allo-HSCT w latach 2014-2015

Fig. 1 - Incidence of viral infections after allo-HSCT in 2014-2015

2012-2013 rozpoznano 205 zakażeń, w tym 197 po allo-HSCT i 8 po auto-HSCT. Natomiast w latach 2014-2015 rozpoznano 264 zakażenia, w tym 262 po allo-HSCT i 2 po auto-HSCT.

W 2012-2013 po allo-HSCT zakażenia wystąpiły u 119 (51,3\%) pacjentów, w tym u ponad połowy z nich (51,2\%) zakażenia wielokrotne: u 58 pacjentów obserwowano zakażenie jednym wirusem, u 29 dwoma, u 16 trzema i u 16 czterema lub więcej. W 2014-2015 po allo-HSCT zakażenia wystąpiły u $162(60,6 \%)$ pacjentów, co oznacza istotny wzrost w stosunku do lat 2012-2013 (OR = 1,47; 95\%CI = 1,-22,12; $\mathrm{p}=0,035)$. U 41,9\% pacjentów wystąpiły zakażenia różnymi wirusami, co oznacza spadek w stosunku do wcześniejszego okresu (OR =0,69; 95\%CI =0,42-1,14; p = 0,122): u 98 pacjentów obserwowano zakażenie jednym wirusem, u 41 dwoma, u 22 trzema i u 5 czterema. Częstość kumulacyjna zakażeń po allo-HSCT wynosiła (2012-2013 vs. 2014-2015): CMV - $28,0 \%$ vs $29,2 \%$, BKV - $18,5 \%$ vs $22,8 \%$, EBV - $15,5 \%$ us $24,3 \%$, ADV - $9,5 \%$ us $5,2 \%$, RV $-9,1 \%$ vs $5,6 \%$, VZV $-2,6 \%$ vs $1,1 \%$, INFL - $0,9 \%$ vs $3,4 \%$, HHV6 - $0,9 \%$ vs $1,5 \%$, NV $0 \%$ us $2,2 \%$, RSV $0 \%$ us $1,5 \%$, PIF $0 \%$ us $0,7 \%$, MPV $0 \%$ vs $0,4 \%$ (Ryc. 1, Tab. I). Po auto-HSCT w latach 2012-2013 wystąpiły zakażenia u 8 (10,5\%) pacjentów: RV - 4, CMV - 2, ADV - 1, BKV - 1, a w latach 2014-2015 u 2 (2,6\%) pacjentów: RV-1, INFL-1.

Pomiędzy zakażeniami poszczególnymi wirusami nie obserwowano różnic w wieku pacjenta oraz medianie czasu od transplantacji do stwierdzenia zakażenia (mediany od 0,6 do 3,3 miesiąca). Jedynie w przypadku zakażenia NV i VZV obserwowano znamiennie dłuższy czas od transplantacji do wystąpienia zakażenia (w latach 2014-2015 odpowiednio 7,7 i 9,6 miesiąca) (Tab. II).

Odsetek wyleczeń z poszczególnych infekcji wzrósł we wszystkich zakażeniach (2012-2013 us 2014-2015): EBV $90,7 \%$ vs $100 \%$, ADV - $93,8 \%$ us $100 \%$, BKV - $94,2 \%$ vs $96,8 \%$, CMV - 94,6\% us $98 \%$, przy czym w obydwu okresach czasu odsetek wyleczeń wynosił $100 \%$ w przypadku zakażeń INFL, VZV, HHV6 i rotawirusowych. Również w grupie nie obserwowanych wcześniej zakażeń wirusami paragrypy, RSV, MPV odsetek wyleczeń również wyniósł 100\% (Tab. III). W grupie pacjentów po allo-HSCT stwierdzono zmniejszenie liczby zgonów z powodu zakażeń wirusowych z 15/232 (6,5\%) w 2012-2013 do 2/267 (0,7\%) w 2014-2015 (p=0,0004; $\mathrm{OR}=9,1 ; 95 \% \mathrm{CI}=2,0-58)$, przy czym u obydwu pacjentów, u których doszło do zgonu, stwierdzano współistnienie zakażeń CMV i BKV.

\section{Omówienie}

Realizacja programu monitorowania powikłań infekcyjnych we wszystkich krajowych pediatrycznych ośrodkach przeszczepiania komórek krwiotwórczych oraz ośrodkach onkologii i hematologii dziecięcej jest niewątpliwie jednym

Tabela I - Trendy w częstości zakażeń wirusowych po allo-HSCT

Table I - Trends in incidence of viral infections after allo-HSCT

\begin{tabular}{|c|c|c|c|c|c|c|c|}
\hline \multirow[t]{2}{*}{ Wirus } & \multicolumn{2}{|c|}{ 2012-2013 } & \multicolumn{2}{|c|}{ 2014-2015 } & \multirow[t]{2}{*}{ Trend } & \multirow[t]{2}{*}{ OR $(95 \% \mathrm{CI})$} & \multirow[t]{2}{*}{$\mathrm{p}$} \\
\hline & $\mathrm{N}=232$ & {$[\%]$} & $\mathrm{N}=267$ & [\%] & & & \\
\hline CMV & 65 & 28,0 & 78 & $29,2 \%$ & $\uparrow$ & $1,1(0,7-1,6)$ & 0,768 \\
\hline EBV & 36 & 15,5 & 65 & $24,3 \%$ & $\uparrow$ & 1,8 $(1,1-2,8)$ & 0,014 \\
\hline VZV & 6 & 2,6 & 3 & $1,1 \%$ & $\downarrow$ & $0,4(0,1-1,9)$ & $0,22 C$ \\
\hline HHV6 & 2 & 0,9 & 4 & $1,5 \%$ & $\uparrow$ & $1,7(0,3-13)$ & 0,515 \\
\hline $\mathrm{ADV}$ & 22 & 9,5 & 14 & $5,2 \%$ & $\downarrow$ & $0,5(0,3-1,1)$ & 0,067 \\
\hline BKV & 43 & 18,5 & 61 & $22,8 \%$ & $\uparrow$ & $1,3(0,8-2,0)$ & 0,236 \\
\hline Grypa & 2 & 0,9 & 9 & $3,4 \%$ & $\uparrow$ & $4,0(0,8-27)$ & 0,056 \\
\hline Paragrypa & - & - & 2 & $0,7 \%$ & $\uparrow$ & - & 0,501 \\
\hline RSV & - & - & 4 & $1,5 \%$ & $\uparrow$ & - & 0,127 \\
\hline MPV & - & - & 1 & $0,4 \%$ & $\uparrow$ & - & 0,999 \\
\hline Rotawirus & 21 & 9,1 & 15 & $5,6 \%$ & $\downarrow$ & $0,6(0,3-1,3)$ & 0,139 \\
\hline Norowirus & - & - & 6 & $2,2 \%$ & $\uparrow$ & - & 0,032 \\
\hline
\end{tabular}

RSV - Respiratory Syncytial Virus; MPV - Metapneumovirus; $\uparrow$ lub $\downarrow$ - wzrost lub spadek częstości zakażeń 
Tabela II - Wiek, czas do zakażenia i czas terapii zakażeń wirusowych po allo-HSCT (2014-2015) Table II - Age, time to infection and time of treatment of viral infections after allo-HSCT (2014-2015)

\begin{tabular}{lccc}
\hline Wirus & Wiek w czasie HSCT [lata] & Czas od HSCT do zakażenia [miesiące] & Czas leczenia [dni] \\
\hline CMV & $12,9(0,3-19)$ & $1,6(0,0-11,2)$ & $17(1-139)$ \\
EBV & $10,7(0,1-19)$ & $1,8(0,3-11)$ & $7(1-21)$ \\
HHV6 & $2,9(1,4-4,3)$ & $1,4(0,6-6,2)$ & $12(1-16)$ \\
VZV & $7(5,0-8,6)$ & $9,6(0,2-13)$ & $10(8-23)$ \\
Polyoma BKV & $11,1(0,1-19)$ & $0,6(0,0-5,8)$ & $2(1-107)$ \\
Adenowirus (ADV) & $9,2(2,4-18,3)$ & $0,7(0-8,2)$ & $11(0-83)$ \\
Grypa i paragrypa & $2,2(0,4-15,0)$ & $0,8(0,0-6)$ & $7(5-34)$ \\
RSV & $8,7(1,4-13)$ & $2,0(0,5-9,1)$ & $8(5-14)$ \\
MPV & 4,2 & 0,6 & 14 \\
Rotawirus & $1,5(0,5-16,5)$ & $3,3(0,0-13)$ & $7(0-25)$ \\
Norowirus & $4,6(1,1-17,7)$ & $7,7(0,0-18)$ & $7(5-20)$ \\
\hline We wszystkich kolumnach podano medianę i zakres wartości. & &
\end{tabular}

Tabela III - Terapia zakażeń wirusowych i jej wyniki po allo-HSCT (z uwzględnieniem nawrotów zakażeń tym samym wirusem)

Table III - Treatment and outcome of viral infections after allo-HSCT (including relapses of infections)

\begin{tabular}{|c|c|c|c|c|c|c|}
\hline Wirus & $\mathrm{N}$ & Terapia celowana & Terapia objawowa & Przeżyli & IRM & Przeżycie (\%) \\
\hline $\mathrm{CMV}$ & 98 & $\begin{array}{l}\text { Gancyklowir }(n=88)^{*} \\
\text { Foskarnet }(n=24) \\
\text { Cydofowir }(n=9) \\
\text { Walgancyklowir }(n=12)\end{array}$ & 1 & 96 & $2(2,0 \%)$ & $98,0 \%$ \\
\hline EBV & 71 & $\begin{array}{l}\text { Rytuksymab }(\mathrm{n}=65) \\
\text { Cydofowir }(\mathrm{n}=1)\end{array}$ & 5 & 71 & 0 & $100 \%$ \\
\hline HHV6 & 7 & $\begin{array}{l}\text { Foskarnet }(\mathrm{n}=3) \\
\text { Gancyklowir }(\mathrm{n}=3)\end{array}$ & 1 & 7 & 0 & $100 \%$ \\
\hline VZV & 3 & Acyklowir $(\mathrm{n}=3)$ & 0 & 3 & 0 & $100 \%$ \\
\hline BKV & 63 & $\begin{array}{l}\text { Cydofowir }(\mathrm{n}=22) \\
\text { Gancyklowir }(\mathrm{n}=4) \\
\text { Foskarnet }(\mathrm{n}=4) \\
\text { Ciprofloksacyna }(\mathrm{n}=8)\end{array}$ & 34 & 6 & $2(3,2 \%)$ & $96,8 \%$ \\
\hline Adenowirus & 15 & $\begin{array}{l}\text { Cydofowir }(\mathrm{n}=11) \\
\text { Gancyklowir }(\mathrm{n}=2)\end{array}$ & 2 & 15 & 0 & $100 \%$ \\
\hline Grypa & 12 & Oseltamiwir $(n=12)$ & 0 & 12 & 0 & $100 \%$ \\
\hline Paragrypa & 2 & $\begin{array}{l}\text { Rybawiryna }(\mathrm{n}=1) \\
\text { Gancyklowir }(\mathrm{n}=2)\end{array}$ & 0 & 2 & 0 & $100 \%$ \\
\hline RSV & 4 & $\begin{array}{l}\text { Rybawiryna }(\mathrm{n}=2) \\
\text { Gancyklowir }(\mathrm{n}=2)\end{array}$ & 0 & 4 & 0 & $100 \%$ \\
\hline MPV & 1 & $\begin{array}{l}\text { Rybawiryna }(\mathrm{n}=0) \\
\text { Gancyklowir }(\mathrm{n}=1)\end{array}$ & 0 & 1 & 0 & $100 \%$ \\
\hline Rotawirus & 18 & & 18 & 18 & 0 & $100 \%$ \\
\hline
\end{tabular}

(*) niektórzy pacjenci byli leczeni więcej niż jednym lekiem; IRM - śmiertelność zależna od infekcji (infection-related mortality)

z najważniejszych przedsięwzięć wieloośrodkowych w hematologii polskiej ostatnich lat [4]. Program ten pozwala na analizę epidemiologii i ocenę skuteczności terapii powikłań infekcyjnych. W tej pracy przedstawiamy aktualizację danych dotyczących zakażeń wirusowych w stosunku do pierwszego raportu opublikowanego w roku 2015.

Podobnie jak w poprzednich latach widać, że zakażenia wirusowe to problem głównie występujący u pacjentów po allo-HSCT, podczas gdy jest to niemalże kazuistyka u pacjentów po auto-HSCT. Jest to konsekwencją znacznych zaburzeń immunologicznych rozwijających się u dużej części pacjentów po allo-HSCT, spowodowanych różnicami antygenów zgodności tkankowej pomiędzy dawcą i biorcą, stosowanymi lekami immunosupresyjnymi oraz rozwojem choroby przeszczep-przeciwko-gospodarzowi (GVHD). $\mathrm{W}$ efekcie u pacjentów po allo-HSCT często dochodzi do reaktywacji wirusów latentnych, głównie herpeswirusów, w tym najczęściej CMV i EBV, które stanowią istotny problem kliniczny po allo-HSCT wiążący się z koniecznością stosowania terapii wyprzedzającej lub celowanej. Często dochodzi również do zakażenia i reaktywacji wirusem polyoma BKV, który powoduje rozwój krwotocznego zapalenia pęcherza moczowego.

Obraz kliniczny zakażeń wirusami latentnymi jest związany z ich efektem bezpośrednim, powodującym rozwój typowej dla danego wirusa choroby (CMV - najczęściej: zapalenie płuc, wątroby, mózgu, przewodu pokarmowego, niewydolność szpiku kostnego; EBV - zespół limfoproliferacyjny PTLD; 
VZV - półpasiec; HHV6 - zapalenie mózgu), jak również efektem pośrednim związanym z negatywnym wpływem na układ odpornościowy przyczyniającym się do rozwoju kolejnych zakażeń, w tym innymi wirusami oraz zakażeń grzybiczych. Niewątpliwie, stosowane leczenie przeciwwirusowe oddziałuje szkodliwie na stan układu odpornościowego, a także na funkcję odnawiającego się szpiku kostnego. Częstym powikłaniem zakażenia wirusowego i stosowanego leczenia przeciwwirusowego jest wtórna niewydolność szpiku kostnego, która wpływa na funkcjonowanie całego organizmu i powoduje niekorzystny efekt postępowania przeszczepowego. Inaczej mówiąc, zakażenia wirusowe mogą zniweczyć wysiłek ośrodka przeszczepowego oraz uzyskany efekt przeszczepienia komórek krwiotwórczych i leczenia przeciwnowotworowego.

W ostatnich latach w polskich ośrodkach pediatrycznych zaobserwowano istotne trendy $\mathrm{w}$ epidemiologii zakażeń wirusowych. Zwiększyła się częstość reaktywacji wirusa EBV, co zapewne wynika ze wzrostu częstości wykonywanych przeszczepień wysokiego ryzyka rozwoju PTLD, tj. od dawcy alternatywnego, z niezgodnością w HLA, z deplecją limfocytów T, powtórnych HSCT, z obecnością GVHD, zwłaszcza steroidoopornej lub przewlekłej wymagającej terapii immunosupresyjnej [5]. Zwiększyła się również częstość zakażeń wirusami oddechowymi, co wiąże się z nawracającymi w ostatnich latach epidemiami grypy. $\mathrm{Na}$ wzrost wykrywalności wirusów CARV ma wpływ poprawa możliwości diagnostycznych i stosowanie w Polsce badań multiplex-PCR dla całego panelu wirusów oddechowych.

W okresie ostatnich 2 lat zaobserwowano również lepszą skuteczność terapeutyczną zakażeń wirusowych u pacjentów po allo-HSCT. Jest to niewątpliwie efekt stosowanych zasad postępowania zalecanego zarówno przez ECIL i inne instytucje, jak również zaangażowania personelu medycznego w szybkie diagnozowanie i leczenie wyprzedzające lub celowane odpowiednich zakażeń.

Należy podkreślić, że w polskich realiach zalecane leczenie pierwszej linii zakażeń obejmuje: gancyklowir (lub walgancyklowir) i foskarnet w CMV [6]; rytuksymab w EBV [5]; cydofowir w polyoma BKV i ADV [7]; gancyklowir lub foskarnet w HHV6 [6]; oseltamiwir w grypie [8] oraz rybawirynę wobec wirusów CARV (paragrypa, RSV, MPV) $[9,10]$.

\section{Wnioski}

Analiza epidemiologii zakażeń wirusowych po HSCT w okresie ostatnich 4 lat wskazuje na wzrost liczby zakażeń po allo-HSCT, w tym znaczący wzrost częstości zakażeń EBV oraz pojawienie się zakażeń wirusami z grupy CARV. Obserwuje się spadek liczby zakażeń wirusowych po auto-HSCT. Często stwierdza się współistnienie infekcji wirusowych. W ostatnich 2 latach nastąpiło zmniejszenie liczby zgonów z powodu zakażeń wirusowych po allo-HSCT.

\section{Wkład autorów/Authors' contributions}

Według kolejności.

\section{Konflikt interesu/Conflict of interest}

Nie występuje.

\section{Finansowanie/Financial support}

Nie występuje.

\section{Etyka/Ethics}

Treści przedstawione $\mathrm{w}$ artykule są zgodne $\mathrm{z}$ zasadami Deklaracji Helsińskiej, dyrektywami EU oraz ujednoliconymi wymaganiami dla czasopism biomedycznych.

\section{P I Ś M I E N N IC T W O/REFERENCES}

[1] Styczyński J. Infections in polish pediatric hematology, oncology and stem cell transplantation centers in 20122013: Incidence report. Med Biol Sci 2014;28:55-61.

[2] Styczyński J, Czyżewski K, Siewiera K, et al. Zakażenia wirusowe u dzieci po przeszczepieniu komórek krwiotwórczych. Acta Haematol Pol 2015;46:312-317.

[3] Marr KA. Delayed opportunistic infections in hematopoietic stem cell transplantation patients: a surmountable challenge. Hematology Am Soc Hematol Educ Program 2012;2012:265-270.

[4] Styczynski J, Czyzewski K, Wysocki M, et al. Increased risk of infections and infection-related mortality in children undergoing haematopoietic stem cell transplantation compared to conventional anticancer therapy: A multicentre nationwide study. Clin Microbiol Infect 2016;22. 179 e171 -179 e110.

[5] Styczynski J, van der Velden W, Fox CP, et al. Management of Epstein-Barr Virus infections and post-transplant lymphoproliferative disorders in patients after allogeneic hematopoietic stem cell transplantation: Sixth European Conference on Infections in Leukemia (ECIL-6) guidelines. Haematologica 2016;101:803-811.

[6] Ljungman P, de la Camara R, Cordonnier C, et al. Management of CMV, HHV-6, HHV-7 and Kposi-Srcoma Hrpesvirus (HHV-8) infections in patients with hematological malignancies and after SCT. Bone Marrow Transplant 2008;42:227-240.

[7] Matthes-Martin S, Feuchtinger T, Shaw PJ, et al. European guidelines for diagnosis and treatment of adenovirus infection in leukemia and stem cell transplantation: Summary of ECIL-4 (2011). Transpl Infect Dis 2012;14:555-563.

[8] Engelhard D, Mohty B, de la Camara R, et al. European guidelines for prevention and management of influenza in hematopoietic stem cell transplantation and leukemia patients: Summary of ECIL-4 (2011), on behalf of ECIL, a joint venture of EBMT, EORTC, ICHS, and ELN. Transpl Infect Dis 2013;15:219-232.

[9] Hirsch HH, Martino R, Ward KN, et al. Fourth European Conference on Infections in Leukaemia (ECIL-4): Guidelines for diagnosis and treatment of human respiratory syncytial virus, parainfluenza virus, metapneumovirus, rhinovirus, and coronavirus. Clin Infect Dis 2013;56:258-266.

[10] Waghmare A, Englund JA, Boeckh M. How I treat respiratory viral infections in the setting of intensive chemotherapy or hematopoietic cell transplantation. Blood 2016;127:2682-2692. 